\title{
Effects of sintering temperature on microstructure and properties of sanitaryware ceramic produced with waste material
}

\author{
E. Martini ${ }^{1 *}$, A. Pavese ${ }^{2}$, D. Tabacchi ${ }^{3}$, D. M. Fortuna ${ }^{1}$, A. Fortuna ${ }^{1}$ \\ ${ }^{I}$ SE.TE.C. Srl, via Enrico Fermi 6/18, 01033 Civita Castellana (VT), Italy \\ ${ }^{2}$ University of Torino, Department of Earth Sciences, Torino, Italy \\ ${ }^{3}$ Minerali Industriali Srl, Novara, Italy
}

\begin{abstract}
This paper aims at exploring the possibility of using a great percentage of recycled materials into vitreous china (VC), thus, contributing to urban waste decrease while lowering the industry's buying costs, previously optimized, for the sanitaryware production. The recycled blend was introduced in the ceramic slip, Sanitser VC, and used in three sanitaryware production plants. This slip let to improve the environmental performances of the overall ceramic production through energy-saving and a decrease in greenhouse gas emissions. In fact, the firing temperature is $80-100{ }^{\circ} \mathrm{C}$ lower than traditional production. Therefore, the objective of this paper was to evaluate the firing behavior, technological properties, and microstructure of a typical industrial vitreous china body in comparison with Sanitser VC. The analytical results confirmed the force of this idea and highlighted the advantages of the choice made.
\end{abstract}

Keywords: glass ceramics, sintering process, microstructure, thermal analysis, X-ray diffraction.

\section{INTRODUCTION}

'Sanitser' project aims to contribute to the vitreous sanitaryware sector innovation by replacing large amounts of virgin raw materials with glass cullet from urban solid waste recycling, resulting in an energy demand decrease during the production. Usually, the remaining scrap after the first industrial waste glass separation is still landfilled; thanks to an advanced separation, Sanitser gives new life and value to this secondary material, providing an extra amount of useful glass to produce new products. The vitreous sanitaryware production typically implies the use of different ceramic materials for the ceramic body [1-7], and introducing glass cullet in these blends reduces virgin raw materials use [8-12]. The glass cullet adopted in Sanitser originates from an advanced treatment process of glass scraps discarded after the primary urban waste separation. This glass, which is mixed with impurities, dirt, and other materials, amounts to around 200,000 ton/year, which can thus be recovered in Italy by SASIL Spa. Besides glass scraps, other recycled raw materials are used to produce the Sanitser VC (as reported in a previous paper [13]). These include ceramic scraps and minerals, taking from the recovery of historical white granite quarries. In recent years, more different uses have also been proposed for the glass, such as stoneware tiles [14-18] and glassceramic foams [19]. In the previous paper [13], the formula of the slip and the data obtained in the laboratory phase of this project, in which different concentrations of this blend were tested, are reported. In the present paper, the

*®https://orcid.org/0000-0002-6203-8675 data provided by the final formula used in three ceramic manufacturers that have been involved in testing Sanitser VC slip at an industrial scale is shown. They led to producing about 2000 sanitaryware pieces.

In this paper, the sanitaryware pieces produced by casting with firing cycles of $17 \mathrm{~h}$ at $1150-1170{ }^{\circ} \mathrm{C}$ in intermittent furnaces were evaluated and compared to conventional $\mathrm{VC}$ production. The objective was to characterize the Sanitser VC sample bodies from three factories and to evaluate its firing behavior and microstructure (porosity and crystalline phases). The main purpose was to corroborate if changes in conditions could improve the fired properties, such as mechanical strength, water absorption, and linear shrinkage [1, 2, 13, 20-23], in compliance with standards [24-27]. Through the knowledge of the microstructure and the characteristics of the ceramic body, one expects that an eventual reformulation of the body slip, introducing such a ceramic blend, positively changes the industrial firing conditions. Adding the mix had a positive effect on quartz dissolution and on the formation of the liquid phase during the sintering. Phase compositions and microstructure by scanning electron microscopy (SEM) and X-ray diffraction (XRD) techniques were investigated. Physical characteristics as mechanical strength, water absorption, and linear shrinkage were evaluated. Porosity and bulk density by Archimedes immersion technique and helium pycnometer were studied on this body. In the end, differential thermal analysis and thermogravimetry (DTA/TG) allowed identifying the reactions at the firing temperature. It is shown that the sintering and the mechanical properties were improved at a lower temperature of firing. 


\section{EXPERIMENTAL}

Materials for body slip: ceramic blend for the Sanitser VC slip (composed of sodium glass GS-VF, pitcher BVCVF, and F60-PBVF) was provided by Minerali Industriali Srl (Novara, Italy). In a previous paper [13], the technical data of the recycled materials inserted into the blend and all the raw materials used for Sanitser and conventional VC are shown. The waste glass GS-VF came from glass bottles, the pitcher BVC-VF came from the recovery of sanitaryware ceramics production, and the F60-PBVF was the recovery of the Verbania 'historical' white granite quarries.

Apparatus: SEM analysis was carried out using a variable pressure scanning electron microscope (Vega3 SBU, Tescan, Czech Republic). Microstructural analysis of the specimens fired at $1165^{\circ} \mathrm{C}$ in three different intermittent kilns was performed with an X-ray diffractometer (D5000, Siemens, Germany). For water absorption test of specimens taken from sanitarywares $[24,25,27]$ from three different companies, a stove thermostat, an electronic balance (BE/95 series, Sassuolo, Italy), and a tank with vacuum were used [27]. Three-point bending tests were performed using a bending test fixture (mod. Mor/1), according to a standard procedure [25], in a mechanical testing machine (Ceramics Instr.). The linear shrinkage measurement [26] was carried out using an electronic caliper (Gabbrielli, Italy). Porosity and bulk density were determined by Archimedes' immersion method and helium pycnometry (MVP-1, Quantachrome Instr., USA). Thermoanalytical techniques such as thermogravimetry (TG) and differential thermal analysis (DTA) were simultaneously conducted (STA 409, Netzsch, Germany).

Methods: the Sanitser slip was produced by SETEC and delivered to three ceramic companies (A, B, and C) at Civita Castellana industrial district, with the aim of getting ceramic pieces similar to traditional pieces, according to the new time-temperature cycle at $1160-1170{ }^{\circ} \mathrm{C}$. To make these trials, the ceramic companies cast, glazed, and fired real pieces (washbasins, WC pans, and bidets), preserving the same working time used in the factory. All cast pieces were sprayed with Sanitser glaze, developed for this body, and then fired in an intermittent kiln.

$X$-ray diffraction $(X R D)$ and SEM analysis of Sanitser bodies: X-ray powder diffraction and SEM analyses were carried out. Quantitative XRD and full structure refinement were used to characterize Sanitser VC body and glaze slip, fired at different temperatures to verify the resulting phase composition. The nature of the phases that appeared upon thermal treatment and the degree of homogeneity achieved for such ceramic bodies [28-30] were characterized.

Characteristics of the fired ceramic bodies: the degree of sintering was estimated by the linear shrinkage $(\Delta \mathrm{L})$ related to the size of $20 \mathrm{~cm}$ (specimens obtained by casting the body in a gypsum mold), modulus of rupture (MOR), and water absorption (WA). After firing, ceramic samples of three companies (A, B, C) were taken. They were tested, and some measurements were carried out to determine flexural strength, total linear shrinkage, and water absorption. 1) MOR (3-point flexural testing): 10 samples (rectangular bars) were cast with Sanitser VC slip in a plaster mold $(20 \times 2 \times 1 \mathrm{~cm})$. The samples were removed from the mold and allowed to dry at $40^{\circ} \mathrm{C}$ for 1 day in an oven. These samples were fired in intermittent kilns in the three factories. The flexural strength of the specimens was measured with a bending test fixture [25]. 2) $\Delta \mathrm{L}$ : in the same way, 3 rectangular bars $(20 \times 3 \times 2 \mathrm{~cm})$ were prepared. The green specimens were fired at 1150-1165 ${ }^{\circ} \mathrm{C}$ in intermittent kilns of the three sanitaryware companies. Following the standards $[25,26]$, the linear shrinkage was calculated by the equation: $\Delta \mathrm{L}(\%)=(\mathrm{Ls}-\mathrm{Lc}) .100 / \mathrm{Ls}$; being $\mathrm{Ls}$ and $\mathrm{Lc}$, the length $(\mathrm{mm})$ of the green and fired specimens, respectively. 3) WA: it was determined by different methods for pieces produced in the three factories. It was calculated following standards for the sanitaryware sector [24, 25, 27]: a) EN 997 and UNI 4543 standards [24, 25]: the fired pieces, after drying and weighing, were boiled in distilled water for $2 \mathrm{~h}$ and immersed in water for 1 day; then the specimens were removed from the water, dried with a cotton cloth, then weighed again; b) AS 1976 standard [27]: the specimens, after drying, were weighed individually to an accuracy of not less than $0.01 \mathrm{~g}$; specimens were placed in a vacuum device and preserved at a vacuum of $30 \mathrm{mmHg}$ for not less than 60 $\mathrm{min}$; then, cold freshly-boiled distilled water was added to the vessel without reducing the vacuum, until the specimens were covered; the specimens were removed and boiled in distilled water for not less than $20 \mathrm{~min}$; after the specimens were cooled in water for not less than $16 \mathrm{~h}$, any surface water was removed with a damp cloth, and specimens were weighed individually.4) Bulk density of green compact: bulk density of unfired compact was determined by weight and geometric measurements to evaluate the apparent volume of the dried specimens. Drying was performed in an electric oven at $110{ }^{\circ} \mathrm{C}$ until constant mass. The bulk density $\left(\mathrm{g} / \mathrm{cm}^{3}\right)$ of a specimen was the dry mass divided by the volume, which was determined from the surface dimensions, namely length, width, and thickness. 5) Specific weight of the fired piece was calculated from the average phase composition (multiplying each phase content determined by XRD by its density given in the literature [31,32]).

Evaluation of porosity and bulk density: the effects of firing time and temperature have been observed on the glass phase formation and some technological properties like porosity and bulk density, which may affect, in turn, the quality of the product. The porosity and bulk density of the sintered bodies were evaluated using Archimedes' immersion method [33-35] and helium pycnometry [36, 37]. The Archimedes immersion method permits evaluating the bulk density, apparent porosity, and volume of the open porosity $\left(\mathrm{V}_{\text {pores }}\right)$. This volume was converted into water mass, and the obtained value was divided by the mass of the dry sample $\left(\mathrm{m}_{\text {sample }}\right)$ to yield the indirectly measured value of WA, which was related to the water saturation of the evaluated materials. Later, the obtained WA was used for comparison with the values determined by the current standards for sanitaryware [24, 25, 27]. Thanks to the 
helium pycnometry, bulk density, specific weight (SW), and $\mathrm{V}_{\text {pores }}$ were calculated. These features allowed to obtain the total porosity and the closed porosity for all bodies [38-40]. Archimedes immersion method: density and porosity can be measured using the Archimedes buoyancy technique with dry weight, soaked weight, and immersed weight in water of ceramic materials. The Archimedes immersion method was reported in ASTM C373-88 [33] procedure: the dried samples were weighed and immersed in boiling water for 5 $\mathrm{h}$. Then the heating system was switched off, and the ceramic pieces remained immersed in water for another $24 \mathrm{~h}$ (water immersion time) for saturation. The excess moisture on the sample surfaces was removed with a damp cloth, and their mass was measured again. The apparent densities of the samples were determined by immersion in water. Each test result was the average of five samples. Helium pycnometer: an aliquot of each sample with dimensions of around $1.3 \times 2$ $\mathrm{cm}$ was collected and dried in an oven at $110 \pm 2{ }^{\circ} \mathrm{C}$ for $4 \mathrm{~h}$. Then, each one was tested by the helium gas pycnometry, yielding the value of the actual volume $\left(\mathrm{V}_{\text {real }}\right)$ of the tested piece (aliquot). Three measurements were made for each sample. Then, it was waterproofed with oil and immersed in water; using the Archimedes' principle [33, 38], as reported [38-40], the parameters total porosity and closed porosity were calculated.

DTA/TG of Sanitser powder (slip): differential thermal analysis and thermogravimetry (DTA-TG) were carried out to study the firing conditions. The STA 409 was the instrument used for simultaneous thermogravimetric and calorimetric analyses from room temperature up to 1100 ${ }^{\circ} \mathrm{C}$. The analyses were conducted in a powder sample, obtained from the slip, under $100 \mathrm{~mL} \cdot \mathrm{min}^{-1}$ flow of nitrogen gas and heating rate of $10{ }^{\circ} \mathrm{C} / \mathrm{min}$. The TG-DTA crucibles were always equipped with a thermocouple for direct measurement of the temperature at the sample or reference crucible (DTA). The DTA can identify the temperature regions and the magnitude of critical events of firing such as drying, binder burnout, carbon oxidation, sulfur oxidation, structural clay collapse, cristobalite transition, $\alpha-\beta$ quartz transition, carbonate decomposition, recrystallization, and melting. TG allows one to control the weight loss of material from a simple process such as drying or from more complex chemical reactions that release gases, such as water release, decomposition, carbonate decomposition, sulfur oxidation, and fluoride oxidation [41-44]. Slip samples were dried in a thermostatic stove for a day. The powder $(25 \mathrm{mg})$ was screened with a 45 -mesh sieve before the test.

\section{RESULTS}

Several laboratory tests were carried out to identify the best-performing formulas of Sanitser VC slip, as reported before [13]. Such tests were carried out on the final Sanitser $\mathrm{VC}$, produced in three different companies, and containing more than $40 \%$ recycled materials.

$X$-ray diffraction (XRD) and SEM analysis of Sanitser bodies: three ceramic bodies (A, B, C), provided by each company, showed the phase compositions reported in Table I. Note that powder diffraction patterns were reprocessed, collected in the previous stage of the project (laboratory tests), using the same profile refinement set-up that was adopted for industrial samples, to provide as similar data processing treatments as possible to extract quantitative phase compositions for samples from both industry and laboratory. This way, systematic errors are reasonably supposed to affect the results from laboratory and from plants alike, thus allowing a fair comparison. Average composition results of the samples A, B, and C, compared with laboratory tests of sample $\mathrm{D}$ and conventional vitreous china, are reported in Table I. VC Sanitser bodies (average and laboratory sample D) were composed with a lower content of quartz and a slightly higher concentration of mullite in comparison with conventional VC. Only samples A and B were analyzed since the ceramic bodies of sample C had the same phase composition as the others. Therefore, it is reasonable that all the involved ceramic bodies of sample $\mathrm{C}$ had morphological features similar to those of samples A and B. In Figs. 1 and 2, SEM micrographs of horizontal and vertical sections of ceramic bodies from samples A and $\mathrm{B}$, respectively, are shown. The samples were analyzed with the same procedure and at the same magnifications.

The bulk phase compositions of samples A, B, and C were studied using X-ray powder diffraction at ambient conditions, with bulk powder samples from the ceramic

Table I - Average phase compositions of bodies of samples A, B, and C after firing at $1163-1170{ }^{\circ} \mathrm{C}$ in comparison with laboratory sample D fired at $1165^{\circ} \mathrm{C}$ and conventional vitreous china fired at $1240{ }^{\circ} \mathrm{C}$.

\begin{tabular}{ccccccc}
\hline Company & $\begin{array}{c}\text { Quartz } \\
(\%)\end{array}$ & $\begin{array}{c}\text { Cristobalite } \\
(\%)\end{array}$ & $\begin{array}{c}\text { Feldspar } \\
(\%)\end{array}$ & $\begin{array}{c}\text { Mullite } \\
(\%)\end{array}$ & $\begin{array}{c}\text { Vitreous phase } \\
(\%)\end{array}$ & $\begin{array}{c}\text { Glass } \\
(\%)\end{array}$ \\
\hline Sample A & 13.3 & 1.2 & 3.0 & 17.1 & - & 65.4 \\
Sample B & 15.0 & 1.2 & 2.5 & 17.4 & - & 63.9 \\
Sample C & 15.7 & 1.3 & 3.5 & 18.3 & - & 61.2 \\
Average & $14.7 \pm 1.2$ & $1.2 \pm 0.1$ & $3.0 \pm 0.5$ & $17.6 \pm 0.6$ & - & $63.5 \pm 2.1$ \\
Laboratory sample D & $13.5 \pm 1.4$ & $2.4 \pm 0.1$ & $3.6 \pm 0.7$ & $18.3 \pm 0.8$ & - & $62.2 \pm 2.6$ \\
Conventional vitreous china & $21.0 \pm 2.5$ & - & $2.5 \pm 0.4$ & $15.5 \pm 0.6$ & $61.0 \pm 3.1$ & - \\
\hline
\end{tabular}



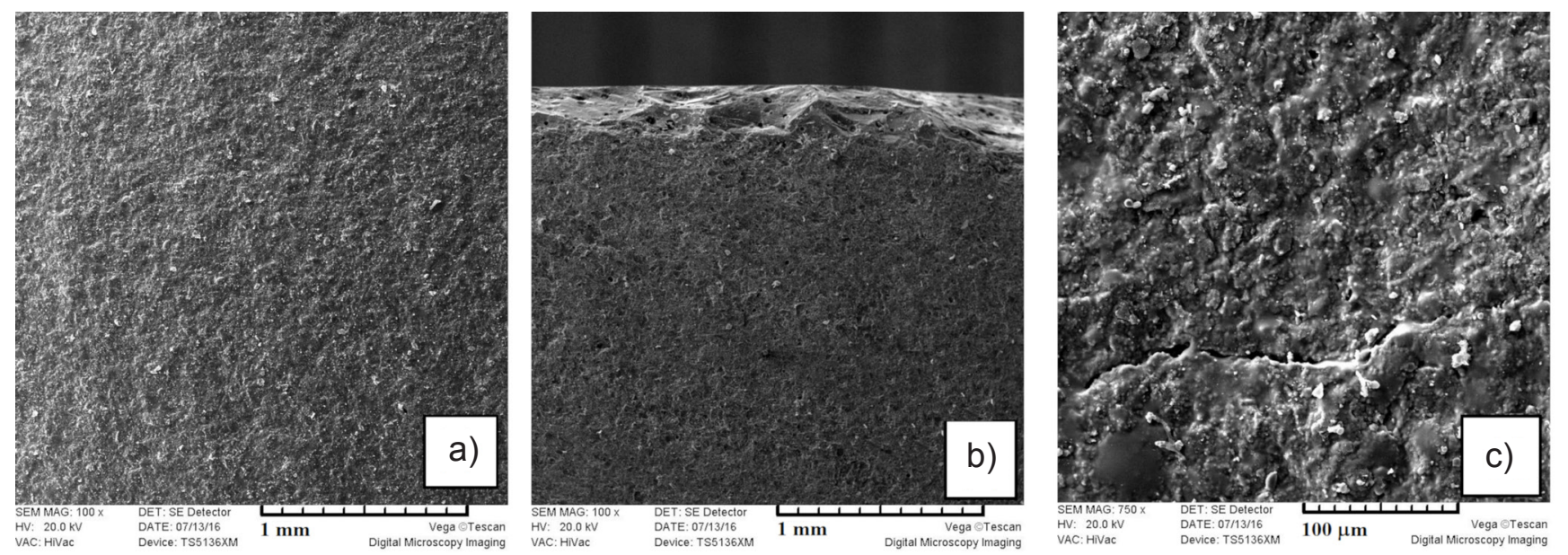

Figure 1: SEM micrographs of a flat surface (a) and vertical section (b) at low magnification, and a region of the flat surface with higher magnification (c) of a ceramic body of sample A.
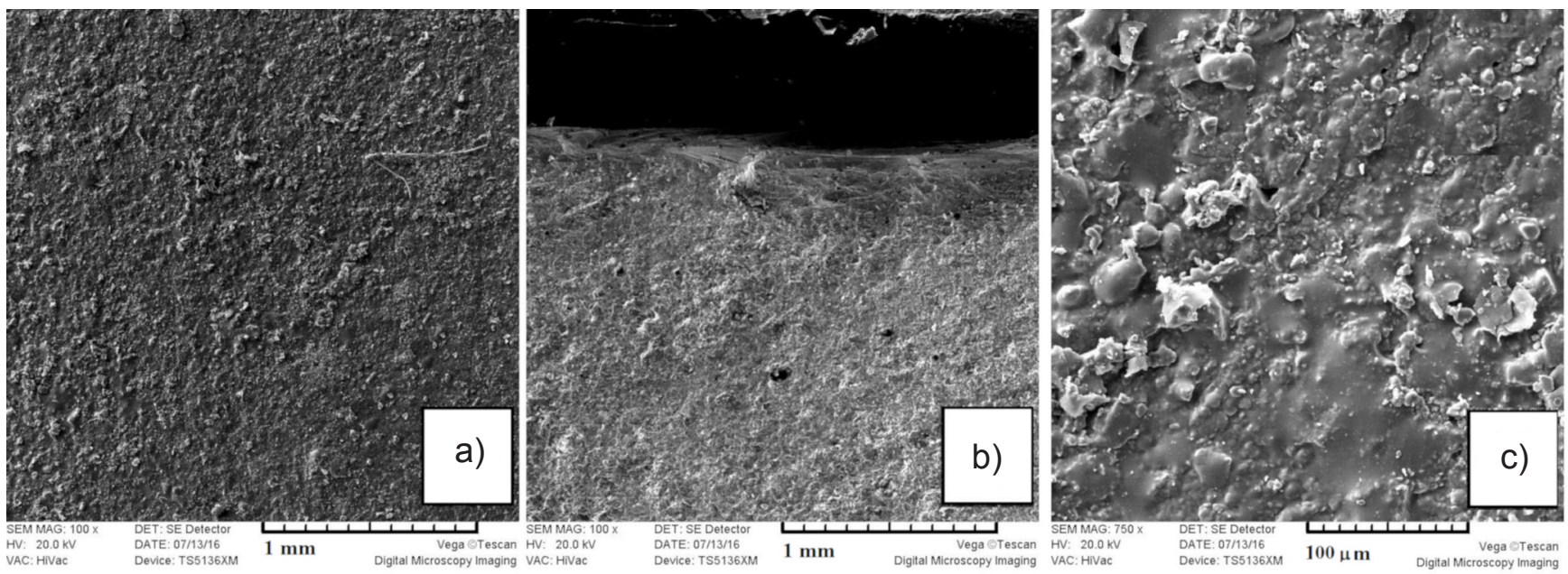

Figure 2: SEM micrographs of a flat surface (a) and vertical section (b) at low magnification, and a region of the flat surface with higher magnification (c) of a ceramic body of sample B.

bodies after removing the glaze, so the results were representative of the pure fired slip. The results were of interest in three aspects: i) a comparison between bodies from the same company, in order to check the intrinsic stability of the slip against 'physiologic' oscillations of a given process; ii) a comparison between products from different companies, which use similar heating cycles and same conventional slip casting, to detect a possible sensibility of the slip to even small differences of the process; iii) a comparison between industrial and laboratory output, to check the 'distance' between wholesale production and small-scale predictions/ expectations. In particular, the following problems had to be tackled: 1) bulk phase compositions of the ceramic bodies from industrial cycles of three different companies (A, $\mathrm{B}, \mathrm{C})$, which tested the slip formulation developed in the project; and 2) degree of bulk homogeneity of the samples from A to C.

Mechanical and physical properties of Sanitser bodies: mechanical and physical properties measured on Sanitser VC samples A, B, and C, and conventional $\mathrm{VC}$ are reported in Table II. These properties are widely used in the evaluation and comparison of product quality and as part of the criteria for selection and use of sanitaryware slips in a variety of industrial applications. The bending strength values in fired Sanitser VC samples were about $17-20 \%$ higher than the conventional VC. Their values of water absorption were smaller than $0.2 \%$, and their shrinkage values were close to the value of conventional VC (fired at $1230-1250{ }^{\circ} \mathrm{C}$ ). The usual methods to evaluate the degree of sintering are: i) linear shrinkage $(\Delta \mathrm{L})$; and ii) water absorption (WA). These methods, however, give incomplete information about densification: WA only measures the open porosity, while $\Delta \mathrm{L}$ is a function of the initial green porosity, i.e., it may vary for different batches. A low value of water absorption suggests a high-level of vitrification [45]. The water absorption values determined with the vacuum absorption method were about twice the results obtained with the boiling method for all samples, including VC body. In fact, during boiling, the air in the pores and channels expands and is partially substituted by water, but some residual amount can remain after boiling. When cooling the piece inside a fluid (water), the air that remains in the pores contracts, creating a negative pressure 
(vacuum) that is the driving force for the fluid to enter the sample. However, when a vacuum system is applied, more effective air withdrawal occurs in the pores and channels, substantially reducing the air remaining inside them. When the vacuum period is interrupted and the piece is dipped into the fluid, the open pores are filled by water more quickly because no residual air counteracts the entry of fluid into the piece. Therefore, in general, the vacuum method [27] gives values higher than other techniques $[24,25]$. The bulk density of green compacts (unfired pieces) were determined, while the specific weight of the fired body was calculated considering the phase contents reported in Table I. Both values were the same order of magnitude for all bodies.

Porosity and bulk density: checking the porosity is fundamental for product quality assessment. Porosity and bulk density measurements were carried out by Archimedes immersion method and helium pycnometry, to get extra information about the porosity. In VC bodies, water absorption decreases with the increase of firing temperature due to the formation of the liquid phase and densification at high firing temperature. Therefore, the determination of porosity is a sign of the densification and the glass phase formation during firing.

Archimedes immersion method: in Table III, the data calculated using the Archimedes immersion method, as explained in literature [33-37, 46], are reported. All the data and the respective standard deviations were the averages of at least five measurements. Apparent porosity $(\mathrm{P})$, water absorption (WA), and bulk density (BD) are properties of fired VC shapes. The water absorption values obtained with the Archimedes immersion method were in compliance with the values determined by the boiling method (Table II); in Sanitser VC, it was about half the value found in the conventional VC. The bulk density values obtained with this method were in compliance with the data of literature $[46,47]$ and were in the range of 1.50 to $2.05 \mathrm{~g} / \mathrm{cm}^{3}$ [48]. The apparent porosity of Sanitser VC was about half of the conventional VC.

Helium pycnometry data: this test was performed to measure the open porosity of the evaluated materials. All data and the respective standard deviations were the averages of at least five measurements. Table IV shows the results of features estimated from the pycnometry test. The bulk density and specific weight were similar for both types of bodies. The value of the specific weight of the fired pieces was in line with that shown in Table II, in which the SW was calculated theoretically, considering the phase composition of each mixture. The bulk density values instead were higher than those measured by the Archimedes immersion method. In the end, the total porosity and closed porosity values were calculated from the bulk density (BD), volume of open porosity $\left(\mathrm{V}_{\text {pores }}\right)$, and specific weight $(\mathrm{SW})$ values obtained by helium pycnometry. Fired specimens were characterized by measuring total porosity as $\mathrm{TP}=(1-\mathrm{BD} / \mathrm{SW}) .100$ and closed porosity as $\mathrm{CP}=\mathrm{TP}-\mathrm{V}_{\text {pores }}$. In Table $\mathrm{V}$, the data obtained for both bodies are reported [38, 39]. Total porosity and closed porosity were calculated with the formula reported in the literature $[32,33]$ that allowed to verify a lower porosity of Sanitser VC. In general, the open porosity decreased with increasing firing temperature due to the formation of a glassy phase that was mainly originated from the feldspar or flux agent. The presence of the recycled blend in Sanitser $\mathrm{VC}$ allowed maintaining a lower total porosity at a lower firing temperature. This value of total porosity corresponded to higher densification in the Sanitser VC. This greater compactness in the microstructure of the Sanitser VC was

Table II - Characteristic data obtained from Sanitser VC slips from three different ceramic companies (A, B, C) in comparison with conventional VC.

\begin{tabular}{lcccc}
\hline Technical parameter & $\begin{array}{c}\text { Sample A fired at } \\
1168{ }^{\circ} \mathrm{C}\end{array}$ & $\begin{array}{c}\text { Sample B fired at } \\
1170{ }^{\circ} \mathrm{C}\end{array}$ & $\begin{array}{c}\text { Sample C fired at } \\
1163{ }^{\circ} \mathrm{C}\end{array}$ & $\begin{array}{c}\text { Conventional VC fired } \\
\text { at } 1240{ }^{\circ} \mathrm{C}\end{array}$ \\
\hline Bending strength after firing* $(\mathrm{MPa})$ & $55.7 \pm 1.7$ & $57.3 \pm 1.8$ & $54.8 \pm 1.5$ & $45.5 \pm 2.5$ \\
Linear firing shrinkage $(\%)$ & $11.2 \pm 0.8$ & $11.5 \pm 0.5$ & $10.5 \pm 0.7$ & $11.0 \pm 0.8$ \\
Water absorption $^{\mathrm{a}}(\%)$ & $0.12 \pm 0.10$ & $0.10 \pm 0.10$ & $0.15 \pm 0.10$ & $0.25 \pm 0.10$ \\
Water absorption $^{\mathrm{b}}(\%)$ & $0.25 \pm 0.30$ & $0.24 \pm 0.20$ & $0.26 \pm 0.20$ & $0.46 \pm 0.10$ \\
Bulk density of green compact $\left(\mathrm{g} / \mathrm{cm}^{3}\right)$ & & $1.81 \pm 0.08$ & & $1.84 \pm 0.09$ \\
Specific weight of fired body $\left(\mathrm{g} / \mathrm{cm}^{3}\right)$ & $2.60 \pm 0.07$ & $2.61 \pm 0.05$ & $2.62 \pm 0.08$ & $2.61 \pm 0.05$ \\
\hline
\end{tabular}

Note: $R S D$ of all individual results $\leq 5.0 \%$; * required value $>39.50 \mathrm{MPa}[25] ;{ }^{a}$ boiling method; ${ }^{b}$ vacuum method.

Table III - Data obtained by Archimedes immersion method for the fired samples of Sanitser and conventional VC.

\begin{tabular}{ccccc}
\hline Sample & $\begin{array}{c}\mathrm{V}_{\text {pores }} \\
\left(\mathrm{cm}^{3}\right)\end{array}$ & $\begin{array}{c}\text { BD } \\
\left(\mathrm{g} / \mathrm{cm}^{3}\right)\end{array}$ & $\begin{array}{c}\mathrm{P} \\
(\%)\end{array}$ & $\begin{array}{c}\text { WA } \\
(\%)\end{array}$ \\
\hline Conventional VC & $0.32 \pm 0.08$ & $1.98 \pm 0.07$ & $0.43 \pm 0.09$ & $0.22 \pm 0.05$ \\
Sanitser VC & $0.12 \pm 0.05$ & $2.05 \pm 0.07$ & $0.26 \pm 0.08$ & $0.13 \pm 0.06$ \\
\hline
\end{tabular}

Note: $R S D$ of all individual results $\leq 5.0 \% ; V_{\text {pores }}:$ volume of open porosity; BD: bulk density; $P$ : apparent porosity; WA: water absorption. 
due to the blend used as raw material, which acted as a flux. It decreased the temperature of the liquid phase formation and the viscosity of the glassy phase $[45,47,49]$. The effect of fluxing ingredient used as an auxiliary component to help the sintering of ceramic product and the formation of the liquid phase in Sanitser VC is reported in the literature [13, 21, 50].

Table IV - Data obtained by helium pycnometry for the fired samples of Sanitser and conventional VC.

\begin{tabular}{cccc}
\hline VC sample & $\mathrm{V}_{\text {pores }}\left(\mathrm{cm}^{3}\right)$ & $\mathrm{BD}\left(\mathrm{g} / \mathrm{cm}^{3}\right)$ & $\mathrm{SW}\left(\mathrm{g} / \mathrm{cm}^{3}\right)$ \\
\hline Conventional & $0.50 \pm 0.08$ & $2.46 \pm 0.18$ & $2.64 \pm 0.09$ \\
Sanitser & $0.30 \pm 0.05$ & $2.48 \pm 0.15$ & $2.60 \pm 0.07$ \\
\hline
\end{tabular}

Note: $R S D$ of all individual results $\leq 5.0 \%$; $V_{\text {pores }}$ : volume of open porosity; BD: bulk density; SW: specific weight.

Table V - Total porosity (TP) and closed porosity (CP) calculated for the fired samples of Sanitser and conventional VC.

\begin{tabular}{ccc}
\hline Sample & $\mathrm{TP}(\%)$ & $\mathrm{CP}(\%)$ \\
\hline Conventional VC & $6.82 \pm 0.26$ & $6.32 \pm 0.25$ \\
Sanitser VC & $4.62 \pm 0.23$ & $4.32 \pm 0.29$ \\
\hline
\end{tabular}

Note: $R S D$ of all individual results $\leq 5.0 \%$.

Thermal analysis of Sanitser slip powder: to study the reaction taking during the heat treatment, the firing was studied in non-isothermal conditions by DTA-TG. Typical TG, DTG (derivative of TG), and DTA curves of the VC body sample and Sanitser VC are shown in Fig. 3. It was noted the thermal behavior of the sedimentary raw materials (clays) was consistent with expectations, according to their chemical and mineralogical compositions. Weight loss events were seen in the TG and DTG curves (Fig. 3a) of the conventional VC body and of the Sanitser VC in the ranges 20-200, 200-400, 400-600, and 600-800 ${ }^{\circ} \mathrm{C}$, whose total weight loss was in the 6.69-6.85\% range for both samples. The DTA curves (Fig. 3b) had a first endothermic peak, which was related to the evaporation of water physically adsorbed on the kaolinite particles. The second peak was due to the dehydration of gibbsite, which was followed by its transformation into alumina. The third peak was mainly associated with the dehydroxylation of kaolinite, which transformed into metakaolinite. A large exothermic peak around $345{ }^{\circ} \mathrm{C}$ was due to the organic matter decomposition observed for the conventional VC sample, while it was not present in the Sanitser VC curve. In addition, an exothermic event within the $978.5-992.8{ }^{\circ} \mathrm{C}$ range was observed. This thermal event can be related to the transformation of the metakaolinite to a spinel structure. In this case, the weight loss within the temperature range of 400 to $600{ }^{\circ} \mathrm{C}$ was due to the dehydroxylation of clays. The disappearance of the exothermic peak between 300 and $450{ }^{\circ} \mathrm{C}$, associated with the combustion of organic materials present in the clays, was certainly due to the effect of glass, which was found in the blend. In fact, obvious rheological changes have been observed in the Sanitser VC, which does not require the addition of deflocculants to disperse the clays $[13,21,50]$.
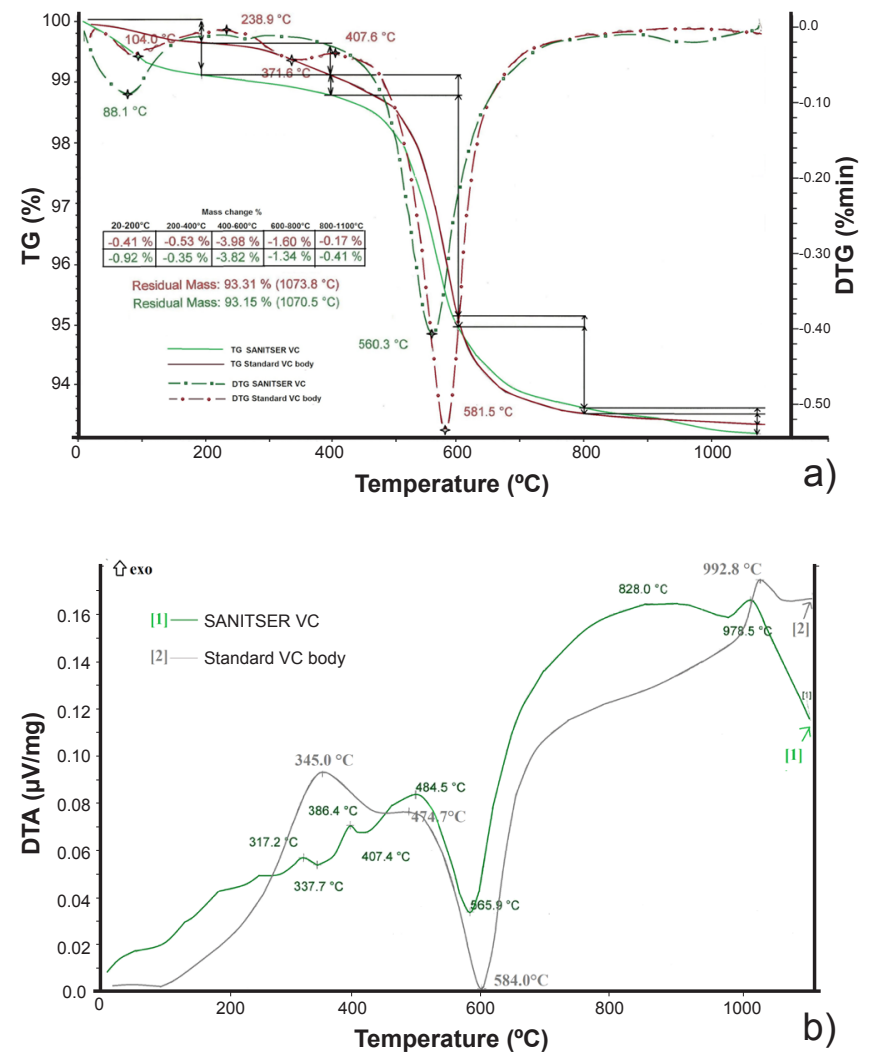

Figure 3: TG-DTG (a) and DTA (b) curves of Sanitser and conventional VC.

\section{DISCUSSION}

The compositions of the samples A, B, and C determined by XRD of bulk powder samples suggested that the fired VC slip was investigated. The laboratory test and industrial production were in agreement (Table I) by comparing the results of the laboratory and the averages of samples $\mathrm{A}, \mathrm{B}$, and $\mathrm{C}$, which showed small oscillations that can be considered 'physiological', considering the difficulties in estimating the large content of the amorphous phase. The averages of samples A, B, and C proved a substantial agreement between the factories for the phase composition of the ceramic samples. In such a view, the heating cycle and the slip casting of samples A, B, and C were homogeneous enough with each other and did not lead to relevant differences in the phase composition; altogether, the slip formulation was robust and not significantly sensitive to the differences experienced in the casting process and firing between the three ceramic companies.

In conclusion for the Sanitser VC body: i) the general morphologic features from the horizontal and vertical sections of samples A and B were similar to each other, and to the sample D treated in the laboratory; samples $\mathrm{A}$ and $\mathrm{B}$ had homogeneous surfaces, and no anomalous microstructure appeared; ii) the thickness of the glaze was small and cannot be observed with sufficient resolution to be separated from the effects due to the intrinsic discontinuity (bulk-surface) of the sample (Figs. $1 b$ and 2b); iii) the degree of compactness was comparable in both samples; this 
result suggested that the particle packing at the slip casting level and the sintering during the firing were accomplished homogeneously in samples A and B; iv) altogether, on the morphological micro-properties, samples $\mathrm{A}$ and $\mathrm{B}$ were consistent with each other, and both resulted in an agreement with the laboratory sample D; and v) a higher content of mullite and a lower concentration of quartz were observed in the Sanitser VC. XRD patterns of the samples fired in the ideal firing temperature interval showed phase compositions with quartz, mullite, and glass (Table I). SEM observations presented the typical microstructure of porcelain consisting of quartz grains held together by a dense matrix composed of primary and secondary mullite crystals (Figs. 1c and 2c) [51,52].

Table II summarizes the bending strength, water absorption, and linear shrinkage of the Sanitser VC and conventional VC. The average bending strength of fired samples of Sanitser VC was 56.0 $\pm 1.3 \mathrm{MPa}$, higher in the changed composition. The values of water absorption $(0.12 \% \pm 0.03 \%)$ and linear shrinkage $(11.1 \% \pm 0.5 \%)$ were comparable to those shown by commercial VC [53-56]. Features such as water absorption, mechanical strength, abrasion resistance, and resistance to stains and chemical agents of fired ceramic materials depend on the porosity, which is developed during the firing from the raw materials that make up the body. Sanitaryware bodies vitrify in the kiln at $1200-1250{ }^{\circ} \mathrm{C}$ and then densify and shrink (thus reducing the pore space). The porosity is thus a sign of its degree of vitrification. The porosity found in ceramic is associated with the raw materials used to prepare the body [57]. In particular, it is reported that the dehydroxylation process of clay (between 400 and $600{ }^{\circ} \mathrm{C}$ ) forms an open porosity, with intercommunication channels below $5 \mu \mathrm{m}$ in the ceramic mixture. At higher temperatures, around 800-1100 ${ }^{\circ} \mathrm{C}$, in the melting process, the liquid phase closes the open porosity by creating small closed pores dispersed throughout the matrix. The largest isolated pores are instead generated by the melting of the fluxes. The interparticle porosity with irregular pores is created by fusing the quartz and feldspar grains at the boundaries with the glassy matrix due to the differences in thermal expansion coefficients. Interparticle porosity (interconnecting pores) is responsible for the fragility of the fired material and, in particular, affects the decrease in mechanical strength and aids crack propagation [58].

By inserting a flux, like the blend used in the Sanitser VC, the increase in shrinkage during sintering is facilitated; in fact, to obtain suitable shrinkage values, the firing temperature must be lower by $80-100{ }^{\circ} \mathrm{C}$. This was essentially due to the decrease in the viscosity of the glassy phase, which allowed a larger and faster pore closure. The change in the composition of the vitreous china ceramic bodies with the inclusion of the blend (Sanitser VC) allowed for a more compact and homogeneous microstructure, with a lower amount of amorphous phase, smaller pores, and narrow pore size distribution, compared to the standard VC. The comparison between Sanitser and conventional VC production showed that the use of a recycled blend as a flux to replace feldspar and quartz in an industrial formulation of sanitaryware is possible. As expected, pore volume $\left(\mathrm{V}_{\text {pores }}\right)$ and porosities decreased, and the bulk density increased during firing [5759]. In particular, Tables III and IV show a slight increase of bulk density in Sanitser VC with a corresponding decrease of about $40-60 \%$ in $\mathrm{V}_{\text {pores }}$, calculated with Archimedes immersion method and helium pycnometry. All data was correlated with better microstructural homogeneity and a lower amount of amorphous phase. Different papers have reported that introducing a flux (partially) provides better technological properties (water absorption and bulk density, overall) at lower firing temperatures, compared to the traditional commercial formulation $[50,60,61]$. These studies are important because they lead to a decrease in the cost of firing due to the lower firing temperature. Additionally, a further cost decrease is given by the lower cost of the waste glasses compared to those of the common fluxes (feldspar, nepheline syenite). As shown in Table V, the total porosity in Sanitser VC decreased by about $30 \%$, thanks to the flux used. The best firing temperature was achieved in the 1150$1170{ }^{\circ} \mathrm{C}$ range when open porosity reached a minimum value, and simultaneously linear shrinkage was maximum. The firing above the vitrification range results in a drastic fall of the physical properties due to forced expulsion of the entrapped gases, resulting in blisters and bloating.

TG and DTG curves (Fig. 3a) showed that the weight loss over the various temperature ranges was of the same order of magnitude for both Sanitser and conventional VC. The curve of DTA (Fig. 3b) showed the decompositions and thermal transformations of the constituents of the bodies. A great difference was seen in the $300-500{ }^{\circ} \mathrm{C}$ range, where the peak of decomposing organic substances disappeared at 345 ${ }^{\circ} \mathrm{C}$ in the Sanitser VC. This effect was due to the behavior of the waste glass, as reported in a previous paper [13].

\section{CONCLUSIONS}

The results of the trials allowed us to compare Sanitser $\mathrm{VC}$ with a conventional VC (vitreous china) body used in the sanitaryware factory. Such formulations yielded similar results of shrinkage and water absorption. Innovation in this research was the use of a blend of glass and other recycled materials in a formulation for sanitaryware (both body and glaze). Besides, for the first time in a VC body, the hard raw materials (quartz and feldspar) were replaced by recycled materials with low contents of free silica. This may allow a ceramic mixture that is less hazardous to the workers' health. At the sintering temperature of $1150-1170{ }^{\circ} \mathrm{C}$, the molten part of the blend promoted the partial dissolution of the quartz phase and the densification process of the vitreous china. As a result, the sintering was improved, and products with lower porosity and higher mechanical properties were obtained. In conclusion, the addition of $40 \%$ blend reduced the sintering temperature and helped to obtain better mechanical properties. The lower firing temperature of Sanitser VC than that of the conventional VC (1230$1250^{\circ} \mathrm{C}$ ) was the most important advantage. So, VC bodies with excellent technological properties were produced in 
industrial plants, and only small differences were observed in comparison with a conventional VC.

\section{ACKNOWLEDGMENTS}

Authors are indebted to SE.TE.C. Srl (Civita Castellana, Italy) for advice on the ceramic bodies formula, and to Minerali Industriali Srl, who supplied materials for vitreous china formulations. This research was co-financed by the European Union, with the project LIFE12 ENV/IT/1095 SANITSER.

\section{REFERENCES}

[1] D.M. Fortuna, Sanitaryware, Faenza Ed., Faenza (2000). [2] D.M. Fortuna, Sanitaryware casting, SE.TE.C. Srl Ed., Civita Castellana (2011).

[3] G. Aliprandi, Principi di ceramurgia e tecnologia ceramica, $2^{\text {nd }}$ ed., E.C.I.G., Genova (1975).

[4] G. Peco, I prodotti ceramici: dalla tradizione all'alta tecnologia, Marzorati Ed., Milan (1991).

[5] W.D. Kingery, K. Bowen, D.R. Uhlmann, Introduction to ceramics, J. Wiley Sons, New York (1975).

[6] G.W. Phelps, "Ceramics monographs - a handbook of ceramics", Verlag Schmidt, Freiburg (1982).

[7] R. Herrmann, "Ceramics monographs - a handbook of ceramics", Verlag Schmidt, Freiburg (1989).

[8] W. Pannhorst, in "Low thermal expansion glass ceramics", H. Bach, D. Krause (Eds.), Springer, Berlin (1995) 1.

[9] J.M. Rincon, M. Romero, Mater. Constr. 46, 242-243 (1996) 91.

[10] S. Fotiadou, M.C. Limbachiya, A.N. Fried, J.J. Roberts, in "Sustainable waste management and recycling: glass waste", Thomas Telford, London (2004) 305.

[11] R. Siikamaki, L. Hupa, in "Recycling and reuse of glass cullet”, K.R. Dhir, C.M. Limbachiya, T.D. Dyer (Eds.), Thomas Telford, London (2001) 135.

[12] F. Andreola, L. Barbieri, A. Corradi, I. Lancellotti, R. Falcone, S. Hreglich, Waste Manage. 25 (2005) 183.

[13] E. Martini, D. Fortuna, A. Fortuna, G. Rubino, V. Tagliaferri, Cerâmica 63, 368 (2017) 542.

[14] S.R. Bragança, C.P. Bergmann, in "Sustainable waste management and recycling: glass waste" (2004) 217.

[15] S.R. Bragança, C.P. Bergmann, Mater. Res. 8, 1 (2005) 39.

[16] A. Tucci, L. Esposito, E. Rastelli, C. Palmonari, E. Rambaldi, J. Eur. Ceram. Soc. 24, 1 (2004) 83.

[17] F. Matteucci, M. Dondi, G. Guarini, Ceram. Int. 28, 8 (2002) 873.

[18] A.P. Luz, S. Ribeiro, Ceram. Int. 33, 5 (2007) 761.

[19] N.F. Youssef, M.F. Abadir, M.A.O. Shater, J. Eur. Ceram. Soc. 18, 12 (1998) 1721.

[20] R. Taurino, I. Lancellotti, L. Barbieri, C. Leonelli, Int. J. App. Glass Sci. 5, 2 (2014) 136.

[21] N. Marinoni, V. Diella, G. Confalonieri, A. Pavese, F. Francescon, Ceram. Int. 43, 14 (2017) 10895.
[22] S.R. Bragança, C.P. Bergmann, Int. J. Ceram. Technol. 6, 2 (2009) 264.

[23] J.S. Reed, Principles of ceramics processing, $2^{\text {nd }} e d$., John Wiley Sons, New York (1998).

[24] UNI EN 997, "Vasi indipendenti e vasi abbinati a cassetta, con sifone integrato", ICS [91.140.70], UNI, Milano (2015).

[25] UNI 4543-2, "Ceramic sanitary appliances: tests on ceramic materials", ICS [91.140.70], UNI, Milano (1986).

[26] ASTM C326-82, "Standard test method for drying and firing shrinkage of ceramic whiteware clays", ASTM Int., West Conshohocken (1997).

[27] AS 1976, "Vitreous china used in sanitary appliances", Stand. Australia (1992).

[28] C. Medina, M. Frías, M.I. Sánchez de Rojas, Constr. Build. Mat. 31 (2012) 112.

[29] M.S. Conconi, M.R. Gauna, M.F. Serra, G. Suarez, E.F. Aglietti, N.M. Rendtorff, Cerâmica 60, 356 (2014) 524.

[30] P.O. Awoyera, J.O. Akinmusuru, A.R. Dawson, J.M.

Ndambuki, N.H. Thom, Cem. Concr. Compos. 86 (2018) 224.

[31] Engineering ToolBox, "Mineral densities", www. engineeringtoolbox.com.

[32] ThoughtCo., "Densities of common rocks and minerals", www.thoughtco.com.

[33] ASTM C373, "Standard test method for water absorption, bulk density, apparent porosity and apparent specific gravity of fired whiteware products", ASTM Int., West Conshohocken (1988).

[34] ASTM C914-95, "Standard test method for bulk density and volume of solid refractories by wax immersion", ASTM Int., West Conshohocken (2004).

[35] ASTM C830-00, "Standard test methods for apparent porosity, liquid absorption, apparent specific gravity, and bulk density of refractory shapes by vacuum pressure", ASTM Int., West Conshohocken (2011).

[36] F. Andreola, M. Romagnoli, P. Miselli, C. Leonelli, Am. Ceram Soc. Bull. 79 (2000) 49.

[37] M.B. Berger, in “Refractories 2010 Conf.", Sout. Afric. Inst. Min. Metal. (2010) 101.

[38] A. Bernasconi, N. Marinoni, A. Pavese, F. Francescon, K. Young, Ceram. Int. 40, 5 (2014) 6389.

[39] E. Eren, Z. Bayer Ozturk, S. Kurama, AKU J. Sci. Eng. 14, OZ5723 (2014) 147.

[40] C.M. Earnest, R.B. Cassel, J. McCurdy, Ceram. Sci. Eng. 1 (2018) 1.

[41] M.S. Conconi, M. Morosi, J. Maggi, P.E. Zalba, F. Cravero, N.M. Rendtorff, Cerâmica 65, 374 (2019) 227.

[42] V. Lach, Ceram. Int. 4, 1 (1978) 28.

[43] H. Baccour, M. Medhioub, F. Jamoussi, T. Mhiri, A. Daoud, Mater. Charact. 59, 11 (2008) 1613.

[44] S. Parveen, S.A. Jahan, Bangladesh J. Sci. Ind. Res. 45, 4 (2010) 387.

[45] A. Bernasconi, V. Diella, A. Pagani, A. Pavese, F. Francescon, K. Young, J. Stuart, L. Tunnicliffe, J. Eur. Ceram. Soc. 31 (2011) 1353.

[46] A.W. Vieira, M.D.M. Innocentini, E. Mendes, T. 
Gomes, A. Demarch, O.R.K. Montedo, E. Angioletto, Mat. Res. 20, 2 (2017) 637.

[47] F. Contartesi, F.G. Melchiades, A.O. Boschi, Cerâmica 65, 376 (2019) 605.

[48] S.S. Owoeye, B.A. Ajayi, O.E. Isinkaye, A.K. Emehige, Int. J. Ceram. Eng. Sci. 1 (2019) 42.

[49] N. Marinoni, D. D'Alessio, V. Diella, A. Pavese, F. Francescon, J. Environ. Manag. 124 (2013) 100.

[50] T.H. Silva, A.C.M. Castro, F.C. Valente Neto, M.M.N.S . Soares, D.S. de Resende, A.C.S. Bezerra, Cerâmica 65, 375 (2019) 426.

[51] N. Marinoni, A. Pagani, I. Adamo, V. Diella, A. Pavese, F. Francescon, J. Eur. Ceram. Soc. 31 (2011) 273.

[52] E.E. Gültekin, G. Topateş, S. Kurama, Ceram. Int. 43 (2017) 11511.

[53] Y. Kobayashi, O. Ohira, E. Kato, J. Am. Ceram. Soc. 75, 7 (1992) 1801.
[54] K. Hamano, M.J. Hirayama, Ceram. Soc. Jap. Int. Ed. 102, 7 (1994) 664.

[55] O.I. Ece, Z. Nakagawa, Ceram. Int. 28, 2 (2002) 131

[56] G. Sthatis, A. Ekonomakou, C.J. Stournaras, C. Ftikos, J. Eur. Ceram. Soc. 24, 8 (2004) 2357.

[57] C. Gil, M.C. Peiró, J.J. Gómez, L. Chiva, E. Cerisuelo, J.B. Carda, Ceram. Int. 336 (2006) 53.

[58] M. Romero, J.M. Pérez, Mater. Construct. 65 (2015) 320

[59] C. Zanelli, M. Raimondo, G. Guarini, M. Dondi, J. Non-Cryst. Solids 357, 16-17 (2011) 3251.

[60] P.S.S. de Medeiros, H.L. Lira, M.A. Rodriguez, R.R. Menezes, G.A. Neves, L.N.L. Santana, J. Mater. Res. Technol. 8, 2 (2019) 2148.

[61] S.S. Owoeye, T.S. Toludare, O.E. Isinkaye, U. Kingsley, Bol. Soc. Esp. Ceram. V. 58 (2019) 77.

(Rec. 11/10/2019, Rev. 30/06/2020, Ac. 24/07/2020) 